\title{
Sustainable Removal of Contaminants by Biopolymers: A Novel Approach for Wastewater Treatment. Current State and Future Perspectives
}

\author{
Teresa Russo ${ }^{1}$, Pierpaolo Fucile ${ }^{2}$, Rosa Giacometti ${ }^{3}$ and Filomena Sannino ${ }^{3, *}$ \\ 1 Institute of Polymers, Composites and Biomaterials, National Research Council of Italy, Viale J. F. Kennedy 54 \\ Pad. 20 Mostra d'Oltremare, 80125 Naples, Italy; teresa.russo@unina.it \\ 2 Department of Advanced Biomedical Sciences, University of Naples Federico II, Via Pansini 5, \\ 80131 Naples, Italy; pierpaolo.fucile@unina.it \\ 3 Department of Agriculture Sciences, University of Naples Federico II, Via Università 100, 80055 Naples, Italy; \\ rosa.giacometti@unina.it \\ * Correspondence: fsannino@unina.it
}

Citation: Russo, T.; Fucile, P.; Giacometti, R.; Sannino, F.

Sustainable Removal of

Contaminants by Biopolymers: A Novel Approach for Wastewater Treatment. Current State and Future Perspectives. Processes 2021, 9, 719. https://doi.org/10.3390/pr9040719

Academic Editor: George Z. Kyzas

Received: 23 March 2021

Accepted: 14 April 2021

Published: 19 April 2021

Publisher's Note: MDPI stays neutral with regard to jurisdictional claims in published maps and institutional affiliations.

Copyright: (c) 2021 by the authors. Licensee MDPI, Basel, Switzerland. This article is an open access article distributed under the terms and conditions of the Creative Commons Attribution (CC BY) license (https:/ / creativecommons.org/licenses/by/ $4.0 /)$.

\begin{abstract}
Naturally occurring substances or polymeric biomolecules synthesized by living organisms during their entire life cycle are commonly defined as biopolymers. Different classifications of biopolymers have been proposed, focusing on their monomeric units, thus allowing them to be distinguished into three different classes with a huge diversity of secondary structures. Due to their ability to be easily manipulated and modified, their versatility, and their sustainability, biopolymers have been proposed in different fields of interest, starting from food, pharmaceutical, and biomedical industries, (i.e., as excipients, gelling agents, stabilizers, or thickeners). Furthermore, due to their sustainable and renewable features, their biodegradability, and their non-toxicity, biopolymers have also been proposed in wastewater treatment, in combination with different reinforcing materials (natural fibers, inorganic micro- or nano-sized fillers, antioxidants, and pigments) toward the development of novel composites with improved properties. On the other hand, the improper or illegal emission of untreated industrial, agricultural, and household wastewater containing a variety of organic and inorganic pollutants represents a great risk to aquatic systems, with a negative impact due to their high toxicity. Among the remediation techniques, adsorption is widely used and documented for its efficiency, intrinsic simplicity, and low cost. Biopolymers represent promising and challenging adsorbents for aquatic environments' decontamination from organic and inorganic pollutants, allowing for protection of the environment and living organisms. This review summarizes the results obtained in recent years from the sustainable removal of contaminants by biopolymers, trying to identify open questions and future perspectives to overcome the present gaps and limitations.
\end{abstract}

Keywords: biopolymers; wastewater treatment; contaminants; sustainable and renewable approach

\section{Introduction}

Wastewater treatments include different methods and techniques with the purpose of restoring, to a desirable quality, water used and/or contaminated by humans or nature. Chemical, biological, or physical processes, or a combination thereof, have been proposed and adopted, but the debate concerning the level of desired quality/purity of water vs costs incurred to achieve that purity is still open.

Water must be brought back to a minimized level of deleterious or dangerous effects for both the environment and the next user, thus defining quality requirements and, consequently, the best technique to use. Pollution represents the introduction (by humans or nature, with similar effects) of something (i.e., contaminants, including heat and sediments) that changes the water quality, making it physically impure, foul, filthy, dirty, stained, or tainted [1]. 
A high water quality level represents, to some extent, the basis of the progress of modern civilization, but unplanned industrialization and urbanization, use of chemicals, agricultural activities, and other factors play a pivotal role in water pollution; thus, the availability of pure water still represents a challenge [2].

Several substances responsible for water pollution are classified as persistent contaminants [3]. Among others, heavy metals, including species containing cadmium, arsenic, lead, chromium, nickel, mercury, zinc, silver, and copper, have been correlated with the onset of chronic diseases and even with death, depending on certain limits in the human body.

Heavy metals are elements that have atomic weights between 63.5 and 200.6 and a specific gravity greater than 5.0 [4]. Metal plating facilities, mining operations, fertilizer industries, tanneries, batteries, paper and pesticides industries, etc., have been identified as responsible for directly or indirectly discharging heavy metals in wastewaters and in the environment, especially in developing countries. Heavy metals are not biodegradable and tend to accumulate in living organisms. Many heavy metal ions are toxic or carcinogenic. Toxic heavy metals include arsenic, zinc, copper, nickel, mercury, cadmium, lead, and chromium [5]. Zinc is essential for human health, for the physiological functions of living tissue, and regulates many biochemical processes. Despite this, high levels of zinc are directly correlated with health problems (i.e., stomach cramps, skin irritations, vomiting, nausea, and anemia) [5]. Likewise, copper is essential in animal metabolism, but the excessive ingestion of copper leads to serious problems, such as vomiting, cramps, convulsions, or even death [6]. Lung and kidney problems, aside from gastrointestinal distress, pulmonary fibrosis, and skin dermatitis, are directly linked to excessive levels of nickel, which is also classified as a human carcinogen [7]. High concentrations of mercury cause impairment of pulmonary and kidney function, chest pain, and dyspnea [8]. Cadmium, classified by the U.S. Environmental Protection Agency as a probable human carcinogen, exposes human health to kidney dysfunction and even death. Lead can cause central nervous system, kidney, liver, and reproductive system damages, as well as basic cellular process and brain dysfunctions. Chromium in two states, $\mathrm{Cr}(\mathrm{III})$ and $\mathrm{Cr}(\mathrm{VI})$, affects human physiology, accumulates in the food chain, and causes severe health problems ranging from simple skin irritation to lung carcinoma.

The effects of heavy metals on human health and their max threshold value are reported in Table $1[9,10]$.

Table 1. Effects of heavy metals on human health and max threshold value.

\begin{tabular}{|c|c|c|c|c|}
\hline Heavy Metal & Major Sources & Route of Entry & Toxicity Effect & $\begin{array}{c}\text { Max Threshold Value } \\
(\mathrm{mg} / \mathrm{L})\end{array}$ \\
\hline Arsenic & $\begin{array}{l}\text { Pesticides, fungicides, } \\
\text { metal smelters }\end{array}$ & Inhalation and ingestion & $\begin{array}{c}\text { Irritation of the respiratory } \\
\text { system, liver and kidney } \\
\text { damage, loss of appetite, } \\
\text { nausea, vomiting }\end{array}$ & 0.02 \\
\hline Cadmium & $\begin{array}{l}\text { Welding, electroplating, } \\
\text { pesticide fertilizer, } \\
\text { Cd-Ni batteries }\end{array}$ & Inhalation and ingestion & $\begin{array}{l}\text { Lung, liver and kidney } \\
\text { damage; irritation of the } \\
\text { respiratory system }\end{array}$ & 0.06 \\
\hline Lead & $\begin{array}{l}\text { Paint, pesticide, smoking, } \\
\text { automobile emission, mining }\end{array}$ & Inhalation and ingestion & $\begin{array}{c}\text { Lung and liver damage, loss of } \\
\text { appetite, nausea }\end{array}$ & 0.1 \\
\hline Mercury & $\begin{array}{l}\text { Pesticides, batteries, } \\
\text { paper industry }\end{array}$ & $\begin{array}{l}\text { Inhalation, ingestion, } \\
\text { absorption through skin }\end{array}$ & $\begin{array}{l}\text { Irritation of the respiratory } \\
\text { system; lung, liver, and kidney } \\
\text { damage; loss of hearing and } \\
\text { muscle coordination }\end{array}$ & 0.01 \\
\hline Zinc & $\begin{array}{l}\text { Refineries, brass manufacturing, } \\
\text { metal plating, plumbing }\end{array}$ & $\begin{array}{l}\text { Inhalation, ingestion, } \\
\text { absorption through skin }\end{array}$ & $\begin{array}{c}\text { Zinc fumes have a corrosive } \\
\text { effect on skin and cause } \\
\text { damage to the } \\
\text { nervous membrane }\end{array}$ & 15 \\
\hline Chromium & Paint, electroplating, metallurgy & $\begin{array}{l}\text { Inhalation, ingestion, } \\
\text { absorption through skin }\end{array}$ & $\begin{array}{l}\text { Lung damage and irritation of } \\
\text { the respiratory system }\end{array}$ & 0.05 \\
\hline Copper & $\begin{array}{l}\text { Mining, pesticide production, } \\
\text { chemical industry, metal piping }\end{array}$ & Inhalation and ingestion & $\begin{array}{l}\text { Anemia, liver, and kidney } \\
\text { damage; stomach and } \\
\text { intestinal irritation }\end{array}$ & 0.1 \\
\hline
\end{tabular}


The removal of the excesses of heavy metals from water for achieving an acceptable level of quality still represents a great challenge in the water purification processes. The European Union (EU) and the World Health Organization (WHO) have identified and tabulated permissible exposure limits of toxic heavy metals in drinking water [11].

Different methods have been used for the removal of heavy metal ions. Chemical precipitation and ion-exchange, and adsorption, as well as membrane filtration and electro-chemical treatment technologies, represent some of the proposed approaches [12]. Intensive efforts continue to be addressed in the sustainable use of agricultural or industrial by-products in wastewater treatment. Adsorption is the mainly used water treatment technique because of its different associated benefits, such as high efficiency, operational simplicity and economy, ease of recovery, and recyclability of materials via regeneration.

Unfortunately, high energy demands together with low metal removal efficiency and high waste production generally represent the disadvantages of the proposed methods [13].

For example, chemical precipitation is characterized by the use of hydroxides to coagulate and flocculate the dissolved pollutant in bigger particle sizes for coarse precipitates. Water media adjustment to specific $\mathrm{pH}$ values is needed. Moreover, very often, additional methods or techniques are necessary for the efficient removal of heavy metals to sufficiently low levels. An example could be the chemical precipitation method followed by an additional step of ion-exchange that has been used in South Africa to treat acidic mine drainage [14]. Coagulation and flocculation may represent simple methods, but excess materials and production of toxic solid waste make the methods difficult to handle and dispose of. On the other hand, electrochemical treatments, such as electro-deposition, represent rather unfavorable and very expensive methods in water treatment, due to their use of electricity. Ion-exchange represents one of widely adopted cost-effective technique for heavy metal ions removal from aqueous solutions thanks to the use of low-cost materials and ion-exchange chambers. However, the method is characterized by a highly sensitivity of the $\mathrm{pH}$ in the aqueous phase and it can be adopted for low concentrated metal solutions [13].

Biologically-based methods involving microorganisms for heavy metal removal have also been proposed and employed. Activated sludge, trickling filters, stabilization ponds, and lagoons have commonly been used for industrial water treatments because of their relatively low cost, but these methods need to be further modified to improve their efficiency. Furthermore, biosorption, a mass transfer process from a liquid to a solid phase through the use of solid phase adsorbents, has been largely adopted because of its simple operational procedures and low cost [15]. A vast variety of agricultural and industrial by-products have also been used to efficiently remove heavy metals from industrial wastewaters. In this context, bio-based molecular compounds have emerged as low-cost materials for effective and efficient heavy metal removal. In particular, different strategies have been proposed, starting from biopolymers such as chitosan or adopting lignin, cellulose, and carbohydrates from coconut shell, jackfruit, maize cob and husk, hazelnut or pecan shells, rice husk or straw, etc. [16]. On the other hand, taking into account environmental and human health problems related to the presence of dyes in wastewater, which is also correlated to transmission modification of sunlight into water, low cost adsorbents such as banana trunk, coconut shell, corn stalks, grape wood, Jerusalem artichoke stalk, mango peels, activated carbon from Nasturtium microphyllum (AC-Nm), orange peels, oil palm fruit fiber, pineapple peels, rice husk, rice straw, tea waste, and walnut shell have been also proposed [17]. In this context, physicochemical characteristics of the proposed solutions, morphological characteristics such as porosity and internal pore distribution, and surface area and nature (hydrophobic and hydrophilic character of the surface), as well as the eventual presence of functional groups, should properly tune dye removal efficiency [17].

Furthermore, at least 700 substances categorized into 20 classes (according to the Norman network) have also been identified in the European aquatic environment as emerging pollutants. These substances (i.e., flame retardants, pharmaceuticals, personal care products, surfactants, gasoline additives and their degradation products, biocides 
and polar pesticides, etc.) are not commonly monitored in the environment, but should be responsible for environmental damages and adverse human or ecological effects. In some cases, emerging pollutants could not be recognized by currently adopted detection methods, or they could be correlated to novel synthesis or production methodologies that create novel sources of emerging pollutants [18].

It is also important to note, some time ago, a little bit of confusion and different definitions for the term "biopolymer", "biodegradable", "renewable resources", etc. Biopolymers represent biodegradable polymers formed from natural sources or entirely biosynthesized by living organisms. The IUPAC (International Union of Pure and Applied Chemists) defines a biopolymer as a substance composed of a single type of biomacromolecule [19]. Polymer degradation begins with macromolecule chain scission and, consequently, the molar mass decreasing [19]. In addition to the raw materials' characteristics or the manufacturing process, chemical and physical polymer microstructure influences biopolymer degradability [20]. Natural polymers are usually readily biodegradable, with a degradation rate generally inversely proportional to the extent of chemical modification [21], with some exceptions (i.e., cellulose) [19,21,22]. For these reasons, Mensitieri et al. (2011) suggest that the polymer degradation rate is affected by different environmental conditions and the actions of different microorganisms [23]. Furthermore, different classifications of polymers have been provided. For example, Tomy J. Gutierrez (2018) includes a classification of edible polymers, namely carbohydrates, proteins, and lipids [24], whilst some authors have proposed a different classification method: polymers directly extracted or removed from plant or animal biomasses; polymers obtained by chemical synthesis, starting from bio-renewable monomers, such as polylactic acid (PLA); and polymers produced by microorganisms such as polyhydroxyalkanoates, cellulose, xanthan, and pullulan [23-27].

In this scenario, widely available natural biopolymers, such as agar, agarose, alginate, carrageenan, cellulose, chitosan, dextran, gelatin, guar gum, pectin, xanthan, and other polymers, have been adopted for different purposes in recent years, due to their tunable features, flexibility, non-toxicity, and biocompatibility, as well as their biodegradability.

This work aims to collect recent advances in sustainable removal of contaminants by biopolymers, additionally providing a focus on the possibility to overcome the present gaps and limitations of the current approaches. Figure 1 provides an overview of different approaches adopted in current biopolymer-based wastewater treatments.

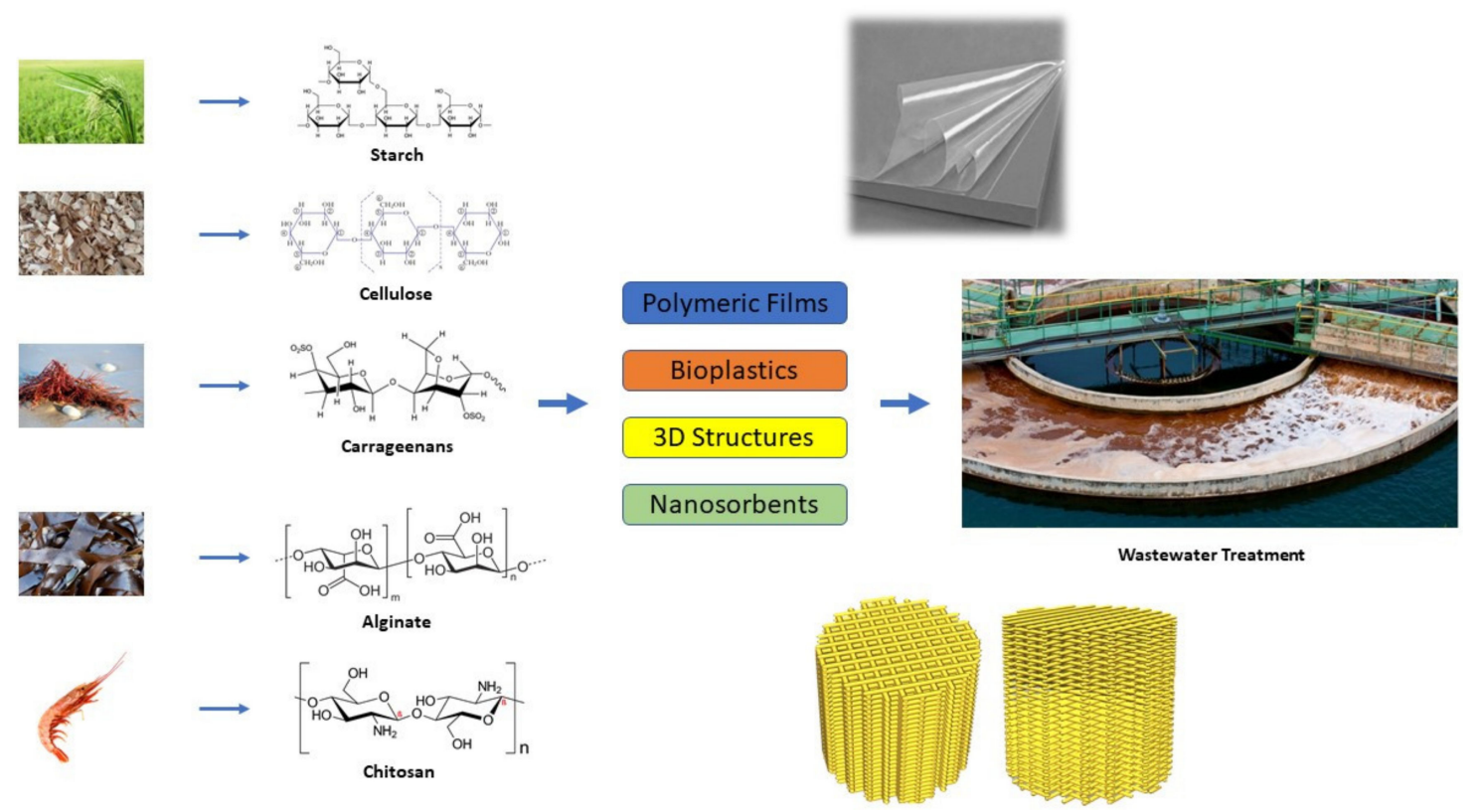

Figure 1. An overview of different approaches adopted in current biopolymer-based wastewater treatments. 


\section{Wastewater Treatment Approaches}

UV photolysis and photocatalysis, adsorption through activated carbon or perovskite, and ozonation are some of the proposed and widely analyzed wastewater treatments for pharmaceutically active compound degradation, as well as for metal ions and toxic dye removal [28-30]. Interestingly, low-cost "greener", "eco-friendly", and renewable alternative biosorbents, based on natural polymers and able to overcome the limitations of actual goldstandard wastewater treatments, have been proposed and analyzed [30,31]. Natural low cost (nano) catalysts at enhanced efficiency represent a focus for wastewater treatment. As an example, different works highlight the possibility to adopt metal- or metal oxide-based nanoparticles (NPs) in nanoscale filtration procedures for pollutant adsorption [31-34]. Nanostructures with peculiar and tailored features, including a large surface area and significant chemical reactivity together with lower power consumption, can lead to the development of multifunctional nanosystems for particle retention and pollutant removal. Available, tunable, and sustainable alternatives, such as natural biopolymer-derived materials from renewable resources, have attracted recent interest due to the decrease in availability of synthetic polymers derived from gas, petroleum, and non-renewable carbon sources [30].

To this aim, a brief and synthetic description of the principal biopolymers and technologies adopted in wastewater treatment has been reported in the following paragraphs.

\subsection{Starch}

Starch represents a natural biocompatible and biodegradable biopolymer commonly found in stalks, roots, and crop seeds of sundry plants. Starch granules with 3D architecture are characterized by a crystallinity between $15 \%$ and $45 \%$ and by D-glucose units with bio-macromolecules including amylopectin, branched $(1 \rightarrow 6) \alpha$-D-glucan, amylose, and linear $(1 \rightarrow 4)$-linked $\alpha$-D-glucan $[35,36]$.

Microcrystalline starch, starch nanocrystal or crystallite, and hydrolyzed starch are obtained via hydrolysis of the crystalline portion of the starch [37]. Different methods for obtaining crystalline and amorphous starch nanostructures have been proposed [30].

Starch nanocrystals have been increasingly utilized as ideal supports for catalyst systems due to their high availability, high surface area, non-toxicity, low cost, renewability, and biocompatibility [30,38-40].

Functionalized natural starches have been proposed as colloidal metal NP-based catalysts. Crosslinked porous starch has been developed by Guo et al. (2013); in particular, the crosslinking of corn starch with epichlorohydrin has been followed by hydrolyzation with $\alpha$-amylase, thus providing a novel biopolymer-based sorbent for Methylene Blue (MB) removal from water [41]. Negatively charged starch has proven to be effective in the adsorption of various cationic dyes [42,43]. Guo et al. (2019) analyzed crosslinked cationic starch for the removal of golden yellow dye from aqueous solutions. The proposed crosslinked cationic starch was obtained starting from corn starch as raw materials, adopting 3-chloro-2-hydroxypropyl trimethylammonium chloride for cationic etherification, and using epichlorohydrin as a crosslinked agent, highlighting a maximum adsorption capacity of about $208.77 \mathrm{mg} / \mathrm{g}$ at $308.15 \mathrm{~K}$ [44]. Magnetic Nanoparticles (MNPs)/starch-g-poly(vinyl sulfate) nanocomposite has been analyzed by Pourjavadi et al. (2016) [43]. Briefly, the work provided interesting results in cationic dyes, Malachite Green and MB, removal from water in successive cycles of adsorption-desorption, through the use of novel magnetic nanosorbents obtained through graft copolymerization of vinyl acetate onto starch in the presence of magnetic nanoparticles. In their work, the authors provided acetate group conversion in hydroxyl groups and, successively, the sulfation of the hydroxyl groups using chlorosulfonic acid. Magnetic Carboxy Methyl Starch (CMS)/poly(vinyl alcohol) hydrogel (mCMS/PVA) was analyzed for MB removal and reused for eight successive cycles [45]. Delval et al. proposed a crosslinked starch containing tertiary amine groups, starting from the reticulation of a starch-enriched flour in the presence of $\mathrm{NH}_{4} \mathrm{OH}$ developing beads with high sorption capacities towards textile dyes [46]. 
Crosslinked-starch graft copolymers containing amine groups have been proposed by Zhang and $\mathrm{Chen}$ (2002) as $\mathrm{Pb}$ (II) and $\mathrm{Cu}$ (II) ions sorbents with $\mathrm{pH}$-dependent features, due to the protonation and deprotonation of the amine groups on the surface [47]. Starch crosslinked with $\mathrm{POCl}_{3}$ and carboxymethylation has been proposed by Kim and Lim for heavy metal ion removal, obtaining a fast kinetic and significant sorption capacity [48].

Metal oxide and metal acid salts of $n$-type semiconductors, including $\mathrm{TiO}_{2}, \mathrm{Fe}_{2} \mathrm{O}_{3}$, $\mathrm{ZnO}$, etc., have been proposed and associated with starch as photocatalysts for photodegradation of environmental contaminants [49-54]. Starch offers additional sustainability/stability to similar graphene nanoparticles [55,56] and carbon nanotubes [57]. In this scenario, easily recoverable magnetic nanocatalysts, obtained by including or decorating metal or metal oxide NPs on the biopolymer surface, open novel perspectives and potential applications for environmental remediation. Sharma et al. (2017) fabricated magnetic Palladium NP catalysts, functionalized with starch and amine ( $\mathrm{Pd} \mathrm{NPs} / \mathrm{Fe}_{3} \mathrm{O}_{4}-\mathrm{NH}_{2} / \mathrm{Starch}$ ), for the reductive amination of nitroarenes in $\mathrm{EtOH}: \mathrm{H}_{2} \mathrm{O}$ at an ambient temperature, reusable in five successive cycles [58]. Crosslinked starches with epichlorohydrin (EPI) have been proposed by Delval et al. (2003) as adsorbents for the recovery of various organic pollutants from aqueous solutions, with the possibility to pack the particles in sorption columns [59]. Carboxyl groups in the polymer networks allow for the significant increase of sorption properties in several crosslinked cyclodextrins and cyclodextrin-carboxymethylcellulose gels, prepared by Crini et al. [60-62]. High sorption capacities for various aromatic derivatives removal from aqueous solutions (chloro- and nitro-phenols, benzoic acid derivatives, dyes, etc.) have been highlighted [60-62].

Janus et al. (2003) proposed 2-hydroxy-3-methacryloyloxy-propyl-beta-cyclo-dextrin as a monomer for the synthesis of cyclodextrin-based materials towards the development of new hydrophilic cyclodextrin (CD) adsorbents, obtained through a radical copolymerization in water using 2-hydroxyethyl methacrylate or vinylpyrolidone as co-monomers. The obtained materials exhibited high sorption capacities toward benzene derivatives [63]. A novel solid phase extraction procedure for trace aromatic compounds in water has been developed by Yu et al. (2003) adopting CD-EPI copolymers and providing a method for improving beads' rigidity by varying the amount of EPI [64]. In the same way, Kitaoka and Hayashi have described the possibility to adopt a highly crosslinked CD-EPI copolymer for Bisphenol A (BPA) removal [65].

On the other hand, starch-graft-poly cationic moiety 2-methacryloyloxyethyl trimethyl ammonium chloride (St-g-PDMC) and starch-graft-poly cationic moiety 2,3-epoxypropyl trimethyl ammonium chloride (St-GTA) have been proposed as greener and low-cost cationic starch flocculants for Chlorella vulgaris and Nannochloropsis salina harvesting from algae-treated Reverse Osmosis Concentrate (ROC), highlighting beneficial results and cost-effectiveness for biomass harvesting, and they are also suitable as dewatering agents for anaerobic sludge $[66,67]$. Furthermore, naturally growing algae in Utah lagoons can uptake nutrients and remediate the wastewater after coagulation and flocculation for separation from wastewater. Cationic corn starch and cationic potato starch with a degree of substitution of 1.34 and 0.82 , respectively, were synthesized using 3-methacryloyl amino propyl trimethyl ammonium chloride and tested on Scenedesmus obliquus and lagoon wastewater. The obtained results highlight that cationic starch has the potential to replace alum for algae harvesting and wastewater treatment, making it a suitable alternative to inorganic coagulants and flocculants [68].

Starch's potential in the removal of various pollutants has been summarized in Table 2. 
Table 2. Starch potential in pollutant removal.

\begin{tabular}{|c|c|c|}
\hline Target Pollutant & Starch & References \\
\hline \multirow{7}{*}{ Dye } & \multirow{7}{*}{ Crosslinked porous sorbents } & Nasrollahzadeh et al. 2020 [30] \\
\hline & & Guo et al. 2013 [41] \\
\hline & & Huang et al. 2014 [42] \\
\hline & & Pourjavadi et al. 2016 [43] \\
\hline & & Guo et al. 2019 [44] \\
\hline & & Gong et al. 2015 [45] \\
\hline & & Delval et al. 2002 [46] \\
\hline \multirow{2}{*}{ Metals } & \multirow{2}{*}{ Crosslinked copolymers } & Zhang and Chen 2002 [47] \\
\hline & & Kim and Lim [48] \\
\hline \multirow{17}{*}{ Organic pollutants } & \multirow{9}{*}{ Composite photocatalysts } & Vilela et al. 2014 [49] \\
\hline & & Malathi et al. 2019 [50] \\
\hline & & Hejri et al. 2013 [51] \\
\hline & & Deependra et al. 2015 [52] \\
\hline & & Vidhya et al. 2015 [53] \\
\hline & & Ma et al. 2016 [54] \\
\hline & & Lin et al. 2014 [55] \\
\hline & & Govan 2020 [56] \\
\hline & & Ihsanullah 2019 [57] \\
\hline & Magnetic nanocatalysts & Sharma et al. 2017 [58] \\
\hline & Crosslinked starches adsorbents & Delval et al. 2003 [59] \\
\hline & \multirow{6}{*}{$\begin{array}{l}\text { Crosslinked cyclodextrins } \\
\text { sorbents/gels }\end{array}$} & Crini 2003 [60] \\
\hline & & Crini et al. 2002 [61] \\
\hline & & Crini 2005 [62] \\
\hline & & Janus et al. 2003 [63] \\
\hline & & Yu et al. 2003 [64] \\
\hline & & Kitaokaet al. 2002 [65] \\
\hline \multirow{2}{*}{ Biomass harvesting } & \multirow{2}{*}{ Cationic crosslinked starch } & Mohseni et al. 2021 [66] \\
\hline & & Wang et al. 2013 [67] \\
\hline
\end{tabular}

\subsection{Cellulose}

Cellulose-based materials have been addressed in different applications from medicine, pharmaceutics, cosmetic products, and biomedicine, as well as in nanocomposites, membranes and barrier films, to electronics and supercapacitors. Cellulose nanofibrils and nanocrystals have been recently investigated as nanosorbents because of their unique and peculiar properties [69-71]. Mohammed et al. (2018) reviewed cellulose-based adsorbents in water and wastewater treatment [72]. Cellulose-based nanomaterials highlighted their efficacy and efficiency in the removal of various contaminants, but their environmental effects, together with their non-toxicity and biodegradability features, still need to be assessed. Cellulose-based nanomaterials' manufacturing costs, their availability, and their life cycle must be considered, taking into account the environmental advantages over activated charcoal-carbon derived materials [72,73]. Membranes for water treatment based on cellulosic nano- and micro-fibers, obtained starting from cellulose nanomaterial mats embedded in a polymer matrix (cellulose triacetate, polypyrrole, poly(ether sulfone), poly(acrylonitrile), poly (ethylene oxide), poly(vinyl alcohol), poly(vinylidene fluoride), and poly(3-hydroxybutyrate)), have been proposed and validated in the field of distillation, hemodialysis, and micro-, nano- and ultra-filtration [74]. Obviously, the combination of polymer matrix and cellulose nanomaterials enormously influences membrane characteristics and behaviour in terms of tensile strength, hydrophilicity, permeability, resistance to biofouling, and enhanced selectivity [74,75]. Beyond this, the possibility of obtaining a uniform and homogeneous dispersion of cellulose in a polymer matrix is still challenging [76,77]. 
The application of cellulose-based materials is affected by limitations related to poor physical stabilities and low adsorption capacities. Consequently, different chemical treatments have recently been adopted for surface modifications of cellulose-based nanomaterials, for the sorption of organic contaminants, or to enhance the affinity for hydrophobic materials [78]. Rezaee et al. (2016) reported that a microbial cellulose (MC) surface impregnated with $\mathrm{TiO}_{2}\left(\mathrm{MC} / \mathrm{TiO}_{2}\right)$ could be used for toluene degradation in air at an ambient temperature under UV-irradiation [79]. Jiang and Hseih (2014) adopted the vapor phase deposition of triethoxyl(octyl)silane on cellulose nanofibers (CNF) aerogels, obtaining reusable water-repellent and oleophilic materials with better sorption capabilities for organic solvents [80]. Wang et al. (2014) studied nanocellulose hydrogels modified with graphene oxide for cyclohexane and dimethylformamide (DMF) sorption [81].

Nanostructured materials based on building blocks have also been proposed for environmental remediation, in the form of nano-porous micro-dimensional systems, in order to avoid eventual toxicological risks correlated with nanotechnologies. Micro- and nano-porous sponge-like systems have been obtained through thermal cross-linking among (2,2,6,6-Tetramethylpiperidin-1-yl)oxyl (TEMPO)-oxidized cellulose nanofibers (TOCNF), citric acid (CA), and branched polyethylenimine (bPEI), with proven sorbent efficiency against different dyes (i.e., Brilliant Blue R, Cibacron Brilliant Yellow, Naphthol Blue Black, Orange II Sodium Salt), also highlighting the possibility to regenerate and reuse the sorbent [82].

Regarding photocatalysis, a novel visible light-responsive material with hierarchical structure, named cotton-PPy-MWCNTs-BiVO assembly method, showing excellent degradation performance for a RB-19 dye solution, thanks to the interaction between polypyrrole (PPy) and multi-walled carbon nanotubes (MWCNTs). The obtained material also exhibited better stability, recyclability and enhanced loading capacity compared to traditional powdery photocatalysts [83].

Self-assembly of 2,2,6,6-tetramethylpiperidine-1-oxyl (TEMPO) oxidized cellulose nanofibril (TO-CNF), crosslinked by Trimethylolpropane-tris-(2-methyl-1-aziridine) propionate (TMPTAP) and polyethyleneimine (PEI), has been proposed in an innovative amino-functionalized nanocellulose aerogel for reversible and efficient adsorption of $\mathrm{Cu}$ (II) ions. A 3D multi-wall perforated cellular structure decorated with amino- and oxygencontaining groups has been obtained. The proposed aerogel was able to return to the original architecture after EDTA-2Na treatment, enabling its recyclability and reversibility [84].

Starting from coconut husk waste and using different surface treatment methods, Johari et al. (2016) developed elemental mercury adsorbents [85]. Korhonen et al. (2011) reported that atomic layer deposition of $\mathrm{TiO}_{2}$ nanoparticles onto cellulose nanomaterial aerogels could be considered a valuable approach for oil and organic solvents' absorption from water surfaces, due to the formation of a low-energy surface layer on the fibers, thus obtaining a nanocellulose-based material with oleophilic and hydrophobic properties [86]. Varghese (2019) showed the adsorption capacity of various lignocellulosic adsorbents for the removal of dyes and heavy metals, even before and after physical and chemical treatment [9]. Beyond this, most of the adsorption studies have been limited to batch-scale, and consequently, they lack pilot or industrial-scale vision for the treatment of real industrial refuse. Moreover, it is important to underline that several pollutants require selective adsorbents. Hydroxyl groups present in cellulose-based adsorbents can be manipulated-also adopting "green" procedures-to activate various reactions or chemical modifications, thus tailoring binding sites and functional groups [87].

Cellulose potential in various pollutants' removal has been summarized in Table 3. 
Table 3. Cellulose potential in pollutant removal.

\begin{tabular}{|c|c|c|}
\hline Target Pollutant & Cellulose & References \\
\hline Dye & Nanosorbents/Nanostructured materials & $\begin{array}{c}\text { Varghese et al. } 2019 \text { [9] } \\
\text { Mohammed et al. } 2016 \text { [72] } \\
\text { Carpenter et al. } 2015 \text { [74] } \\
\text { Rezaee et al. } 2016 \text { [79] } \\
\text { Wang et al. } 2014 \text { [81] } \\
\text { Riva et al. } 2020 \text { [82] } \\
\text { Yan et al. } 2020 \text { [83] }\end{array}$ \\
\hline Heavy metals & Nanostructured materials & $\begin{array}{c}\text { Yan et al. } 2020 \text { [83] } \\
\text { Mo et al. } 2019 \text { [84] } \\
\text { Johari et al. } 2016 \text { [85] }\end{array}$ \\
\hline Organic pollutants/oil & Aerogels & Korhonen et al. 2011 [86] \\
\hline
\end{tabular}

\subsection{Carrageenan}

Carrageenans or carrageenins, also known as "little rocks", are a family of linear sulfated polysaccharides extracted from red edible seaweeds and widely used in the food industry as gelling, thickening, and stabilizing agents. The three main varieties of carrageenan (kappa-carrageenan, iota-carrageenan, and lambda-carrageenan) differ in their degree of sulfation.

Kappa-carrageenan-coated superparamagnetic iron oxide nanoparticles have been proposed by Salguerio et al. (2013) [88] for assisted removal of MB from aqueous solutions. The resulting superparamagnetic composite nanoparticles contained about $12 \mathrm{wt} \%$ carrageenan and showed an MB uptake ability dependent on the $\mathrm{pH}$ of the solution and resulted in promising eco-friendly materials for MB removal through magnetic separation [88].

Furthermore, kappa-carrageenan/poly(glycidyl methacrylate) (CG/PG) hydrogel containing numerous functional groups used as an environmental-friendly adsorbent for adsorptive removal of cationic MB has been studied and characterized, showing that some parameters should affect the adsorption of MB (i.e., CG/PG ratios, initial dye concentration, solution $\mathrm{pH}$, time, adsorbent dosage, and solution temperature). Resulting materials highlighted enhanced adsorption capacity and stability when compared to the neat CG biopolymer [89]. More recently, a zeolite hydrogel composite (ZHC) based on kappacarrageenan and AQSOA-Z05 zeolite and obtained via graft-copolymerization technique, using the crosslinked hydrogel of $\mathrm{KC}$ as polymer matrix, has been proposed for MB dye adsorption. ZHC showed excellent adsorption behavior for six continuous adsorptiondesorption cycles and should be used as an adsorbent for the treatment of cationic dyecontaminated wastewater [90].

A simple approach for bio-inspired underwater superoleophobic membranes via the treatment of hydrolyzed polyacrylonitrile (h-PAN) membranes with naturally obtained kappa-carrageenan and a nanoclay laponite have been considered effective in removing soluble/insoluble organic pollutants from water. In particular, high-viscous oil, due to its highly adhesive nature, requires efficient antifouling and oil-water separation materials, often designed starting from hydrogels-forming species with low-adhesive superoleophobicity. The control of hydrogel thickness and membrane pore size and porosity is a key element in the field of interest. A layer-by-layer (LbL) deposition technique has been adopted for obtaining self-assembled membranes with nanosized pore laponite/CGNmodified membranes, characterized by an excellent adsorption of water-soluble dyes [91].

Ecofriendly carbon aerogels derived from sodium lignin sulfonate and kappa-carrageenan have been studied for efficient dye adsorption, highlighting that lignin sulfonate should be adopted in multifunctional pulping wastewater and $\mathrm{MB}$ dye removal in wastewater treatment [92]. Abdellatif et al. (2020) developed safe, eco-friendly, and cheap magnetic aerogels via the physical cross-linking of iota-carrageenan and polyamidoamine (PAMAM) dendrimer in the presence of different amounts of magnetic nanoparticles $(1 \%, 3 \%$, and $5 \%$ ). The adsorption behavior of the aerogels was evaluated for $\mathrm{Cr}(\mathrm{VI}), \mathrm{Co}^{2+}, \mathrm{Cu}^{2+}, \mathrm{Cd}^{2+}$, $\mathrm{Mn}^{7+}$, and Alphanol fast blue dye, highlighting high removal efficiency [93]. 
The immobilization of spirulina maxima through active entrapment in kappa-carrageenan was investigated by Cañizares et al. (1994) for tertiary treatment of diluted aerationstabilized swine waste. The immobilized algae were submitted to a few repeated cycles for the effluent [94].

Table 4 summarizes the carrageenans' potential for various pollutants' removal.

Table 4. Carrageenans' potential for pollutants' removal.

\begin{tabular}{ccc}
\hline Target Pollutant & Carrageenan & References \\
\hline Dye & Superparamagnetic nanoparticles & Salgueiro et al. 2013 [88] \\
& Hydrogels & Lapwanit et al. 2018 [89] \\
& Mittal et al. 2020 [90] \\
& Self-assembled porous membranes & Prasannan et al. 2020 [91] \\
& Aerogels & Lv et al. 2020 [92] \\
\hline Heavy metal ions & Magnetic aerogels & Abdellatif et al. 2020 [93] \\
\hline Organic pollutants/Oil & Active compound & Cañizares et al. 1994 [94] \\
\hline
\end{tabular}

\subsection{Alginate}

Alginate has been considered among low-cost biomaterials and is characterized by linear block copolymers comprising two uronic acid residues, e.g., $\beta$-D-mannuronic and $\alpha$-L-guluronic acid linked by $\beta$-1,4-glycosidic bonds.

Different applications have been suggested for alginate-based compounds. Recent works have highlighted that alginate is extensively utilized in wastewater remediation for the adsorption of contaminants, due to its nontoxic nature, stability, biodegradability, and water permeability [95-100].

Stable biohydrogel beads have been successfully adopted as a catalytic support material due to their advantages relating to network structure, surface moieties, and to their high surface area [101,102]. Core/shell Fe/Ag NPs obtained through calcium alginate beads modified with aminothiophenol have been proposed by Gupta et al. (2014) for the reduction of 2-NP and 4-NP in wastewater using $\mathrm{NaBH}_{4}$ [103].

Hybrid and reusable (for six successive cycles) beads obtained by mesoporous calcium alginate and titania were tested for $\mathrm{Cd}^{2+}, \mathrm{Co}^{2+}, \mathrm{Cr}^{3+}, \mathrm{Cr}^{6+}$, and $\mathrm{Cu}^{2+}$ ions wastewater removal [104]. Advanced nano-networks have been produced by Zheng et al. (2016) via carbothermal reduction and acid treatment of $\mathrm{Ca}^{2+}$ sodium alginate biohydrogel, resulting in a novel catalyst characterized by a good dispersion of NPs and stability of nanocatalysts [105].

Macromolecular hydrogels' organization in a 3D network structure represents the key element for alginate-based biosorbents, which are also characterized by selective cationic interactions with multivalent ions, such as $\mathrm{Ca}^{2+}, \mathrm{Fe}^{3+}, \mathrm{Ba}^{2+}, \mathrm{Ag}^{+}, \mathrm{Al}^{3+}$, etc. [106-109]. In this context, crosslinked alginate/polyacrylamide hydrogels have been proposed by Yang et al. (2013) using a variety of multivalent cations, thus forming a biopolyanionic network [108]. Furthermore, Ag NPs have been fabricated by Ai et al. (2012) through a specific ecofriendly light-driven technique for in situ growth on a magnetic alginate/magnetite hybrid (Ag@AMH) biohydrogel, characterized by uniformly dispersed $\mathrm{Ag}^{+}$ions, thus causing a catalytic reduction of $4-\mathrm{NP}$ in aqueous solutions [32].

Hybrid alginate/montmorillonite/polyaniline (Alg/MMT/PANI) nanocomposites for $\mathrm{Cr}^{6+}$ removal have been obtained via chemical oxidative polymerization, whilst enhanced Meth-bent/Alg nanosorbents have been processed by integrating methionine-modified bentonite onto sodium alginate [110].

Ahmadi et al. (2016) fabricated heterogeneous core/shell $\mathrm{Fe}_{3} \mathrm{O}_{4}$ /alginate magnetic nanocomposites for the degradation of bisphenol A from aqueous media [111].

Calcium alginate-based hydrogel beads have also been proposed by Asadi et al. (2018) for methyl Violet (MV) removal from aqueous solutions [112]. Parlayici adopted sol-gel chemistry to develop alginate-coated perlite beads for the efficient removal of methylene 
blue, malachite green, and methyl violet from dilute aqueous solutions, highlighting that it was possible to optimize adsorption efficiency by varying mixing time, initial dye concentration, and adsorbent dose, as well as $\mathrm{pH}$ and temperature [113]. Novel biocompatible, eco-friendly, and low-cost adsorbent composites (Sodium Alginate/titania nanoparticle) $\left(\mathrm{SA} / \mathrm{n}-\mathrm{TiO}_{2}\right)$ have been proposed for dye adsorption from colored aqueous solutions, while also evaluating the effect of different parameters (i.e., $\mathrm{SA} / \mathrm{n}-\mathrm{TiO}_{2}$ composition, initial dye concentration, and pH) [114]. Rezaei et al. (2016) developed $\mathrm{Fe}_{3} \mathrm{O}_{4}$ nanoparticles encapsulated with alginate beads for $\mathrm{MB}$ adsorption from synthetic wastewater, evaluating the effect of dye concentration, dose of $\mathrm{Fe}_{3} \mathrm{O}_{4}$ in beads, adsorption time, and intensity of magnetic field adsorption efficiency, while also applying the Taguchi method for optimization of operating conditions in dye adsorption onto the magnetic alginate beads [115].

Radoor et al. (2020) obtained a novel PVA/SA/ZSM-5 zeolite membrane with a good regeneration capacity via a solvent casting technique for dye adsorption, adopting a model anionic dye, Congo red [115]. The proposed membranes also exhibited antibacterial features against Gram-positive (Staphylococcus aureus) and Gram-negative bacteria (Escherichia coli) [116]

Table 5 highlights alginates' potential for various pollutants' removal.

Table 5. Alginates' potential in pollutants' removal.

\begin{tabular}{|c|c|c|}
\hline Target Pollutant & Alginate & References \\
\hline Organic pollutants/Oil & $\begin{array}{c}\text { Molecular imprinted } \\
\text { chitosan- } \mathrm{TiO}_{2} \text { nanocomposite }\end{array}$ & Ahmed et al. 2018 [95] \\
\hline \multirow[t]{3}{*}{ Heavy metal ions } & Beads & $\begin{array}{c}\text { An et al. } 2015 \text { [97] } \\
\text { Idris et al. } 2012 \text { [98] } \\
\text { Kuang et al. } 2015 \text { [99] } \\
\text { Li et al. } 2013 \text { [100] } \\
\text { Wang et al. } 2017 \text { [102] } \\
\text { Wu et al. } 2012 \text { [103] }\end{array}$ \\
\hline & Hydrogels & $\begin{array}{l}\text { Zheng et al. } 2016 \text { [105] } \\
\text { Cheng et al. } 2012 \text { [106] } \\
\text { Topuz et al. } 2012 \text { [107] } \\
\text { Yang et al. } 2013 \text { [108] } \\
\text { Dodero et al. } 2020 \text { [109] }\end{array}$ \\
\hline & Nanocomposites & Ahmad and Mirza 2015 [110] \\
\hline \multirow[t]{2}{*}{ Dye } & Beads & $\begin{array}{l}\text { Asadi et al. } 2018 \text { [112] } \\
\text { Parlayici } 2019 \text { [113] }\end{array}$ \\
\hline & Biocomposites & $\begin{array}{l}\text { Mahmoodi et al. } 2011 \text { [114] } \\
\text { Rezaei et al. } 2016 \text { [115] } \\
\text { Radoor et al. } 2020 \text { [116] }\end{array}$ \\
\hline
\end{tabular}

\subsection{Chitin and Chitosan}

Chitin and chitosan, together with cellulose, represent the most abundant biopolymers available in nature. Chitosan is essentially composed of N-deacetylated chitin, present in insect cuticles and crustaceous shells. It represents a renewable and biodegradable carbohydrate, characterized by the linear aminopolysaccharide of glucosamine. Chitin deacetylase allows enzymatic N-deacetylation for the bioconversion of chitin into chitosan.

Applications in the agricultural/industrial fields, as biocatalysts in wastewater treatment, in drug or gene delivery, and in cell/enzyme immobilization have been widely investigated for hydrophobic chitosan, characterized by high sorption capacity and being readily available for chemical and functional modifications [30,117].

Innovative, sustainable, and renewable nanocatalysts, based on eco-friendly and lowcost nanomaterials, have been under rigorous investigation. In particular, chitosan-based coagulants and flocculants have also been applied in dye and metal ion removal from wastewater [118]. 
Chitosan with a low acetylation degree exhibited a large number of amine groups available for protonation [119], although adsorption features were dependent on the nature of dyes [120] rather than on the deacetylation or acetylation degree [30,121]. The efficient wastewater treatment through multifunctional bio-hybrid aerogels based on cellulose nanofibers, decorated with chitin nanocrystals (CNC), has been reported by Gopi et al. (2017) [122]. Hybrid bio-aerogels were obtained via a freeze-drying procedure by varying the CNCs percentage and were decorated on the CNFs; they were reusable five times without activity or efficiency losses.

Crosslinked chitosan/sepiolite composites have been developed by Marrakchi et al. (2016) for reactive orange 16 and MB removal from aqueous solutions, adopting sepiolite epichlorohydrin as an additive and crosslinker, respectively [123]. In addition, magnetic chitosan nanocomposites using a glutaraldehyde cross-linking agent have been adopted for Acid Red-2 elimination from textile wastewater by Kadam and Lee (2015) [124]. Moreover, fascinating nanocatalysts could be obtained by combining $\mathrm{Fe}_{3} \mathrm{O}_{4}$ and chitin/chitosan toward a hassle-free separation through magnetic support. In this context, magnetic nanosorbents have been designed by Chang and Chen (2005), starting from carboxymethylated chitosan, highlighting excellent results in anionic dye removal from aqueous solutions [125]. Shoueir et al. (2019) analyzed a visible-light photocatalyst obtained by layers of nanostructured $\mathrm{Au} / \mathrm{TiO}_{2}$ on a chitosan fiber substrate, adopted for various water pollutants' degradation (carbofuran (CBN), MB, MNZ) and for the reduction of $\mathrm{Cr}(\mathrm{VI})$ in the presence of citric acid [126].

Magnetic chitosan-based biosorbents based on different molecular weights of chitosan were also crosslinked/stabilized with kappa-carrageenan. With increasing the molecular weight of chitosan, bigger magnetic nanoparticles have been obtained. Studies based on eriochrome black-T (EBT) removal by magnetic biosorbents showed that adsorption capacities are $\mathrm{pH}$-dependent and that mild conditions $(\mathrm{pH}=9)$ should be useful in recycling and reusing the bioadsorbents without alterations in removal efficiency [127].

However, the adsorption capacity of NPs embedded into or stabilized onto chitin/chitosan-substrates results in the possibility to obtain nanocatalysts or nanosorbents with improved features towards the development of natural polymer-based nanocomposites [128]. To this aim, recently, chitin/chitosan-based bio(nano)composites have been combined with different nanostructures (i.e., iron oxide- $\mathrm{Fe}_{3} \mathrm{O}_{4}$, titanium dioxide- $\mathrm{TiO}_{2}$, etc.) $[129,130]$. Rajeswari et al. (2016) proposed PVA-chitosan and PEG-chitosan composites [131] to remove aqueous nitrate ions. Carboxymethyl chitosan nanocomposites have been studied for the complexation of $\mathrm{Cd}^{2+} / \mathrm{Cr}^{6+}$, whilst goethite/chitosan nanocomposites have been proposed for $\mathrm{Pb}^{2+}$ complexation [132,133].

Pincus et al. (2018) proposed chitosan-based bead photocatalysts obtained by decorating CS beads, crosslinked with copper, with nano- $\mathrm{TiO}_{2}$. These photocatalysts have been adopted for arsenite oxidation in UV light or for selective adsorption of As(III) and As(V) in the presence of phosphate [134].

Conducting polymers have also been combined with chitosan for their ion-exchange features, thus providing interesting features in the field of capacitive deionization (CDI). As an example, Abdi et al. [135] demonstrated that enhanced stability of polypyrrole materials could be obtained by combining polypyrrole and chitin/chitosan, due to - $\mathrm{COOH}$ and $-\mathrm{NH}_{2}$ groups. In this case, Zhang et al. (2019) has analyzed a nanoelectrode obtained via in-situ polymerization of polypyrrole (PPy)/CS/CNT, varying the mass ratios of PPy and $\mathrm{CS}$, highlighting interesting results for copper ion absorption from water/wastewater [136].

Water-soluble chitosan-based flocculants have been obtained by Wang et al. (2009) by grafting chitosan with (2-methacryloyloxyethyl) trimethyl ammonium chloride for application in pulp mill wastewater treatment [137].

Nanocomposites obtained through the stabilization of various NPs on organic renewable supports have also been shown by Chen et al. (2015) [138] for organic pollutant removal. In their work, the agglomeration of metal/metal oxide NPs has been reduced thanks to an amino functionalization of organic supports in mild conditions. 
In this context, Muraleedaran et al. (2015) studied the antimicrobial properties of a novel photocatalyst based on chitosan nanocomposites, obtained by adopting ZnO NPs as reinforcement and/or natural antimicrobial agents, highlighting improved antimicrobial features against Gram-negative and Gram-positive bacteria (E. coli and S. aureus) when compared to neat chitosan [139]. Chitosan/ $\mathrm{TiO}_{2}$ (nano)composite photocatalysts have been obtained by Hamdi et al. (2015) and by Neghi et al. (2019) [140,141]. $\mathrm{TiO}_{2} \mathrm{NPs}_{\text {embedded in }}$ chitosan or in a polyvinyl alcohol-chitosan blend (PVA-CS) highlighted enhanced stability in aqueous media at different $\mathrm{pH}$ values for $\mathrm{PVA}-\mathrm{CS}-\mathrm{TiO}_{2}$ when compared to $\mathrm{CS}-\mathrm{TiO}_{2}$, and they could be reused for up to 15 cycles under UV exposure as an effective photocatalyst without a significant loss of catalytic performance [140,141].

Additionally, an innovative approach has been proposed by Antony et al. (2019), anchoring bimetallic AgNi NPs on $\mathrm{Fe}_{3} \mathrm{O}_{4}$ chitosan core/shell substrate, providing interesting results as a reusable (seven times) heterogeneous nanocatalyst able to be recovered/separated using an external magnet [142].

Nanosorbents and polysaccharide-based adsorbents have also been adopted for biosorption of pesticides and organic/inorganic contaminants from water. Chitosan showed its removal efficiency in removing $(>90 \%)$ a herbicide (oxadiazon) from aqueous solutions [143].

Beyond this, adsorption efficiency has been strictly correlated with a multitude of factors, including the chemistry of pollutant and adsorbent characteristics, crosslinking degree, crystallinity, and stiffness of chitosan linkages, etc. [144]. Mi et al. (2002) reported a wet phase inversion protocol for the synthesis of bundle-like porous chitosan beads, useful for anti-inflammatory drug (indomethacin) adsorption [145].

Important advancements and improvements in antimicrobial, UV blocking, and magnetic properties have also been highlighted for chitin/chitosan modified with metal/metal oxide NPs. Chitosan's potential in various pollutants' removal has been summarized in Table 6.

Table 6. Chitins' and Chitosans' potential in pollutants' removal.

\begin{tabular}{ccc}
\hline Target Polluttant & References \\
\hline Dyes & Particles & Gibbs et al. 2003 [119] \\
& Serogels & Goha et al. 2006 [120] \\
& & Marrackhi et al. 2016 [123] \\
& Composites & Kadam and Lee 2015 [124] \\
& & Chang and Chen 2005 [125] \\
& Shouier et al. 2019 [126] \\
& & Karimi et al. [127] \\
\hline Metals & & Anaya-Esparza et al. 2020 [129] \\
& & Li et al. 2010 [130] \\
& & Rajeswari et al. 2016 [131] \\
& Composites & Borsagli et al. 2015 [132] \\
& & Rahimi et al. 2015 [133] \\
& & Abdi et al. 2017 [135] \\
& & Zhang et al. 2019 [136] \\
\hline Organic pollutants/Oil & Water-soluble flocculants & Wang et al. 2009 [137] \\
& & Chen et al. 2015 [138] \\
& & Hamdi et al. 2015 [140] \\
& & Neghi et al. [141] \\
& & Antony et al. 2019 [142] \\
& Nanosorbents & Arvand et al. 2009 [143] \\
\hline Drug/emerging polluttants & Beads & Mi et al. 2002 [144] \\
\hline
\end{tabular}




\section{Conclusions}

The present work set the goal of collecting recent highlights in wastewater treatment by adopting different biopolymers, noting their abundance and availability, together with their tunable structural, physicochemical, biomechanical, and biological features. The possibility to obtain polymer-based reusable and/or renewable materials actually represents the key elements in the field of water and wastewater treatment.

To this aim, emerging nanotechnologies have recently appeared with the purpose of making industrial water remediation more effective, low cost, eco- and environmentalfriendly, as well as greener.

Since the years 2006 and 2007, the European Union has conducted a study about the biopolymers market (Table 7), demonstrating a huge potentiality application [145].

Table 7. European Union (EU): Total internal and external imports and production of biopolymers in 2006-2007.

\begin{tabular}{ccc}
\hline $\begin{array}{c}\text { Market EU } \\
\text { (Countries 27) }\end{array}$ & Imports Volume \\
\hline Internal imports & 2006 & 2007 \\
\hline Main internal production & 192.1 & 216.5 \\
Major producer (Sweden) & 164.0 & 195.5 \\
External imports & 53.3 & 69.2 \\
Main external production & 428.6 & 383.9 \\
Major producer (Singapore) & 404.3 & 367.0 \\
Total imports & 310.0 & 258.7 \\
\hline
\end{tabular}

Modified from Wysokińska, 2010 [145].

However, the main limitations of the proposals consist in the impossibility to implement the experimental procedures in practical applications and in variable environmental conditions while most of the studies are predominantly limited to a laboratory scale. As an example, at low pollutant concentrations, some authors are able to define a precise range of doses/parameters for optimal coagulation and flocculation, thus avoiding water quality deterioration. Obviously, when the volume of interest increases, dose adjustment needs to be applied.

Beyond this, all of the novel/innovative materials for water and wastewater treatments have to be set in the contrasting view to the linear model of "take-make-waste", adopting a careful design for the project of biopolymer-based composites, while also taking into account pollutants of emerging concern, together with emerging production technologies connected to novel sources of emerging pollutants. Considerable efforts still need to be employed in the context of the circular economy, aiming to gradually decouple growth from the finite resources' consumption and taking into account the regeneration of natural systems in the vision to design waste and pollution, keeping in mind the need to adopt products and materials into use.

An analysis of the biopolymers markets, with special reference to starch, hemicellulose, cellulose, alginate, and natural polymers such as chitosan, has demonstrated that these products have the greatest development potential.

Author Contributions: All the authors contributed equally to the review. Conceptualization, T.R. and F.S.; Formal Analysis, T.R., P.F., R.G., F.S. Investigation, T.R., R.G., F.S. Writing-Original Draft Preparation, T.R., F.S. Writing-Review and Editing, T.R., F.S. Visualization, T.R., P.F., R.G.; Supervision, F.S. All authors have read and agreed to the published version of the manuscript.

Funding: This research received no external funding.

Institutional Review Board Statement: Not applicable.

Informed Consent Statement: Not applicable. 


\section{Data Availability Statement: Not applicable.}

Conflicts of Interest: The authors declare no conflict of interest.

\section{References}

1. Englande, A., Jr.; Krenkel, P.; Shamas, J. Wastewater Treatment \& Water Reclamation. In Reference Module in Earth Systems and Environmental Sciences; Elsevier: Amsterdam, The Netherlands, 2015.

2. Vakili, M.; Rafatullah, M.; Salamatinia, B.; Abdullah, A.Z.; Ibrahim, M.H.; Tan, K.B.; Gholami, Z.; Amouzgar, P. Application of chitosan and its derivatives as adsorbents for dye removal from water and wastewater: A review. Carbohydr. Polym. 2014, 113, 115-130. [CrossRef] [PubMed]

3. Ahmed, Q.; Bat, L.; Ali, Q.M. Heavy metal levels in Thunnus albacares (Bonnaterre, 1788) from Karachi fish harbour, Pakistan. Pak. J. Mar. Sci. 2012, 21, 13-21.

4. Srivastava, N.K.; Majumder, C.B. Novel biofiltration methods for the treatment of heavy metals from industrial wastewater. J. Hazard. Mater. 2008, 151, 1-8. [CrossRef] [PubMed]

5. Oyaro, N.; Ogendi, J.; Murago, E.N.; Gitonga, E. The contents of Pb, Cu, Zn and Cd in meat in nairobi, Kenya. J. Food Agric. Environ. 2007, 5, 119-121.

6. Paulino, A.T.; Minasse, F.A.; Guilherme, M.R.; Reis, A.V.; Muniz, E.C.; Nozaki, J. Novel adsorbent based on silkworm chrysalides for removal of heavy metals from wastewaters. J. Colloid Interface Sci. 2006, 301, 479-487. [CrossRef]

7. Borba, C.; Guirardello, R.; Silva, E.; Veit, M.; Tavares, C. Removal of nickel (II) ions from aqueous solution by biosorption in a fixed bed column: Experimental and theoretical breakthrough curves. Biochem. Eng. J. 2006, 30, 184-191. [CrossRef]

8. Namasivayam, C.; Kadirvelu, K. Uptake of mercury (II) from wastewater by activated carbon from an unwanted agricultural solid by-product: Coirpith. Carbon 1999, 37, 79-84. [CrossRef]

9. Varghese, A.G.; Paul, S.A.; Latha, M.S. Remediation of heavy metals and dyes from wastewater using cellulose-based adsorbents. Environ. Chem. Lett. 2019, 17, 867-877. [CrossRef]

10. Singh, R.; Gautam, N.; Mishra, A.; Gupta, R. Heavy metals and living systems: An overview. Indian J. Pharmacol. 2011, 43, 246-253. [CrossRef]

11. Zia, Z.; Hartland, A.; Mucalo, M. Use of low-cost biopolymers and biopolymeric composite systems for heavy metal removal from water. Int. J. Environ. Sci. Technol. 2020, 17, 4389-4406. [CrossRef]

12. Fu, F.; Wang, Q. Removal of heavy metal ions from wastewaters: A review. J. Environ. Manag. 2011, 92, 407-418. [CrossRef]

13. Gunatilake, S. Methods of removing heavy metals from industrial wastewater. Methods 2015, 1, 14 .

14. Feng, D.; Aldrich, C.; Tan, H. Treatment of acid mine water by use of heavy metal precipitation and ion exchange. Miner. Eng. 2000, 13, 623-642. [CrossRef]

15. Akpor, O.; Muchie, M. Remediation of heavy metals in drinking water and wastewater treatment systems: Processes and applications. Int. J. Phys. Sci. 2010, 5, 1807-1817.

16. Bansode, R.; Losso, J.; Marshall, W.; Rao, R.; Portier, R. Adsorption of metal ions by pecan shell-based granular activated carbons. Bioresour. Technol. 2003, 89, 115-119. [CrossRef]

17. Nayeri, D.; Mousavi, S.A. Dye removal from water and wastewater by nanosized metal oxides-Modified activated carbon: A review on recent researches. J. Environ. Health Sci. Eng. 2020, 18, 1671-1689. [CrossRef] [PubMed]

18. Geissen, V.; Mol, H.; Klumpp, E.; Umlauf, G.; Nadal, M.; van der Ploeg, M.; van de Zee, S.E.A.T.M.; Ritsema, C.J. Emerging pollutants in the environment: A challenge for water resource management. Int. Soil Water Cons. 2015, 3, 57-65. [CrossRef]

19. Vert, M.; Doi, Y.; Hellwich, K.-H.; Hess, M.; Hodge, P.; Kubisa, P.; Rinaudo, M.; Schué, F. Terminology for biorelated polymers and applications (IUPAC Recommendations 2012). Pure Appl. Chem. 2012, 84, 377-410. [CrossRef]

20. La Rosa, A. Life cycle assessment of biopolymers. In Biopolymers and Biotech Admixtures for Eco-Efficient Construction Materials; Pacheco-Torgal, F., Ivanov, V., Karak, N., Jonkers, H., Eds.; Woodhead Publishing: Sawston, UK, 2016; pp. 57-78.

21. Rendón-Villalobos, R.; Ortíz-Sánchez, A.; Tovar-Sánchez, E.; Flores-Huicochea, E. The Role of Biopolymers in Obtaining Environmentally Friendly Materials. In Composites from Renewable and Sustainable Materials; Poletto, M., Ed.; Intechopen: London, UK, 2016.

22. Vroman, I.; Tighzert, L. Biodegradable polymers. Materials 2009, 2, 307-344. [CrossRef]

23. Mensitieri, G.; Di Maio, E.; Buonocore, G.G.; Nedi, I.; Oliviero, M.; Sansone, L.; Iannace, S. Processing and shelf life issues of selected food packaging materials and structures from renewable resources. Trends Food Sci. Technol. 2011, 22, 72-80. [CrossRef]

24. Gutiérrez, T.J. Polymers for food applications: News. In Polymers for Food Applications; Springer: Berlin/Heidelberg, Germany, 2018; pp. 1-4.

25. Martău, G.A.; Mihai, M.; Vodnar, D.C. The use of chitosan, alginate, and pectin in the biomedical and food sectorBiocompatibility, bioadhesiveness, and biodegradability. Polymers 2019, 11, 1837. [CrossRef]

26. Ruban, S.W. Biobased packaging-application in meat industry. Vet World 2009, 2, 79-82. [CrossRef]

27. Nampoothiri, K.M.; Nair, N.R.; John, R.P. An overview of the recent developments in polylactide (PLA) research. Bioresour. Technol. 2010, 101, 8493-8501. [CrossRef]

28. Cai, Z.; Dwivedi, A.D.; Lee, W.-N.; Zhao, X.; Liu, W.; Sillanpää, M.; Zhao, D.; Huang, C.-H.; Fu, J. Application of nanotechnologies for removing pharmaceutically active compounds from water: Development and future trends. Environ. Sci. Nano 2018, 5, 27-47. [CrossRef] 
29. Garba, Z.N.; Xiao, W.; Zhou, W.; Lawan, I.; Jiang, Y.; Zhang, M.; Yuan, Z. Process optimization and synthesis of lanthanum-cobalt perovskite type nanoparticles $\left(\mathrm{LaCoO}_{3}\right)$ prepared by modified proteic method: Application of response surface methodology. Korean J. Chem. Eng. 2019, 36, 1826-1838. [CrossRef]

30. Nasrollahzadeh, M.; Sajjadi, M.; Iravani, S.; Varma, R.S. Starch, cellulose, pectin, gum, alginate, chitin and chitosan derived (nano) materials for sustainable water treatment: A review. Carbohydr. Polym. 2020, 251, 116986. [CrossRef]

31. Crini, G. Non-conventional low-cost adsorbents for dye removal: A review. Bioresour. Technol. 2006, 97, 1061-1085. [CrossRef]

32. Ai, L.; Yue, H.; Jiang, J. Environmentally friendly light-driven synthesis of Ag nanoparticles in situ grown on magnetically separable biohydrogels as highly active and recyclable catalysts for 4-nitrophenol reduction. J. Mater. Chem. 2012, 22, 23447-23453. [CrossRef]

33. Meng, Z.-D.; Zhu, L.; Choi, J.-G.; Park, C.-Y.; Oh, W.-C. Preparation, characterization and photocatalytic behavior of WO ${ }_{3}-$ fullerene $/ \mathrm{TiO}_{2}$ catalysts under visible light. Nanosc. Res. Lett. 2011, 6, 1-11. [CrossRef]

34. Zhang, Z.; Sèbe, G.; Rentsch, D.; Zimmermann, T.; Tingaut, P. Ultralightweight and flexible silylated nanocellulose sponges for the selective removal of oil from water. Chem. Mater. 2014, 26, 2659-2668. [CrossRef]

35. Visakh, P.; Mathew, A.; Oksman, K.; Thomas, S. Starch-based bionanocomposites: Processing and properties. In Polysaccharide Building Blocks: A Sustainable Approach to the Development of Renewable Biomaterials; Habibi, Y., Lucia, L.A., Eds.; Wiley: Hoboken, NJ, USA, 2012; pp. 287-306.

36. Zobel, H. Molecules to granules: A comprehensive starch review. Starch-Stärke 1988, 40, 44-50. [CrossRef]

37. Le Corre, D.; Bras, J.; Dufresne, A. Starch nanoparticles: A review. Biomacromolecules 2010, 11, 1139-1153. [CrossRef] [PubMed]

38. Ghaderi, A.; Gholinejad, M.; Firouzabadi, H. Palladium deposited on naturally occurring supports as a powerful catalyst for carbon-carbon bond formation reactions. Curr. Org. Chem. 2016, 20, 327-348. [CrossRef]

39. Ghaedi, M.; Sadeghian, B.; Pebdani, A.A.; Sahraei, R.; Daneshfar, A.; Duran, C. Kinetics, thermodynamics and equilibrium evaluation of direct yellow 12 removal by adsorption onto silver nanoparticles loaded activated carbon. Chem. Eng. J. 2012, 187, 133-141. [CrossRef]

40. Gholinejad, M.; Saadati, F.; Shaybanizadeh, S.; Pullithadathil, B. Copper nanoparticles supported on starch micro particles as a degradable heterogeneous catalyst for three-component coupling synthesis of propargylamines. RSC Adv. 2016, 6, $4983-4991$. [CrossRef]

41. Guo, L.; Li, G.; Liu, J.; Meng, Y.; Tang, Y. Adsorptive decolorization of methylene blue by crosslinked porous starch. Carbohydr. Polym. 2013, 93, 374-379. [CrossRef]

42. Huang, J.; Chang, P.R.; Lin, N.; Dufresne, A. Polysaccharide-Based Nanocrystals: Chemistry and Applications; John Wiley \& Sons: Hoboken, NJ, USA, 2014.

43. Pourjavadi, A.; Abedin-Moghanaki, A.; Tavakoli, A. Efficient removal of cationic dyes using a new magnetic nanocomposite based on starch-g-poly (vinylalcohol) and functionalized with sulfate groups. RSC Adv. 2016, 6, 38042-38051. [CrossRef]

44. Guo, J.; Wang, J.; Zheng, G.; Jiang, X. A TiO 2 / crosslinked carboxymethyl starch composite for high-efficiency adsorption and photodegradation of cationic golden yellow X-GL dye. Environ. Sci. Pollut. Res. 2019, 26, 24395-24406. [CrossRef]

45. Gong, G.; Zhang, F.; Cheng, Z.; Zhou, L. Facile fabrication of magnetic carboxymethyl starch/poly(vinyl alcohol) composite gel for methylene blue removal. Int. J. Biol. Macromol. 2015, 81, 205-211. [CrossRef]

46. Delval, F.; Crini, G.; Morin, N.; Vebrel, J.; Bertini, S.; Torri, G. The sorption of several types of dye on crosslinked polysaccharides derivatives. Dyes Pigments 2002, 53, 79-92. [CrossRef]

47. Zhang, L.-M.; Chen, D.-Q. An investigation of adsorption of lead (II) and copper (II) ions by water-insoluble starch graft copolymers. Colloids Surf. A Physicochem. Eng. Asp. 2002, 205, 231-236. [CrossRef]

48. Kim, B.; Lim, S.-T. Removal of heavy metal ions from water by cross-linked carboxymethyl corn starch. Carbohydr. Polym. 1999, 39, 217-223. [CrossRef]

49. Vilela, C.; Pinto, R.; Pinto, S.; Marques, P.; Silvestre, A.; Freire, C. Polysaccharide Based Hybrid. Materials Metals and Metal. Oxides, Graphene and Carbon Nanotubes; Springer: Berlin, Germany, 2014; Volume 53, ISBN 9783030003463.

50. Malathi, A.N.; Singh, A.K. Antimicrobial activity of rice starch based film reinforced with titanium dioxide $\left(\mathrm{TiO}_{2}\right)$ nanoparticles. Agric. Res. J. 2019, 56, 111. [CrossRef]

51. Hejri, Z.; Seifkordi, A.A.; Ahmadpour, A.; Zebarjad, S.M.; Maskooki, A. Biodegradable starch/poly (vinyl alcohol) film reinforced with titanium dioxide nanoparticles. Int. J. Miner. Metall. Mater. 2013, 20, 1001-1011. [CrossRef]

52. Deependra, K.B.; Swadesh, K.P.; Subhankar, P. An investigation of optical properties of zinc oxide nanoparticle synthesized by starch mediated assembly and its application in photocatalytic bleaching of methyl green and rhodamine-B. Mat. Sci. Semicond. Proc. 2015, 39, 691-701.

53. Vidhya, K.; Saravanan, M.; Bhoopathi, G.; Devarajan, V.P.; Subanya, S. Structural and optical characterization of pure and starch-capped ZnO quantum dots and their photocatalytic activity. Appl. Nanosci. 2015, 5, 235-243. [CrossRef]

54. Ma, J.; Zhu, W.; Tian, Y.; Wang, Z. Preparation of Zinc Oxide-Starch Nanocomposite and Its Application on Coating. Nanoscale Res. Lett. 2016, 11, 200. [CrossRef]

55. Lin, S.T.; Thirumavalavan, M.; Jiang, T.Y.; Lee, J.F. Synthesis of ZnO/Zn nano photocatalyst using modified polysaccharides for photodegradation of dyes. Carbohydr. Polym. 2014, 105, 1-9. [CrossRef]

56. Govan, J. Recent Advances in Magnetic Nanoparticles and Nanocomposites for the Remediation of Water Resources. Magnetochemistry 2020, 6, 4949. [CrossRef] 
57. Ihsanullah. Carbon nanotube membranes for water purification: Developments, challenges, and prospects for the future. Sep. Purif. Technol. 2019, 209, 307-337. [CrossRef]

58. Sharma, H.; Bhardwaj, M.; Kour, M.; Paul, S. Highly efficient magnetic Pd (0) nanoparticles stabilized by amine functionalized starch for organic transformations under mild conditions. Mol. Catal. 2017, 435, 58-68. [CrossRef]

59. Delval, F.; Crini, G.; Vebrel, J.; Knorr, M.; Sauvin, G.; Conte, E. Starch-modified filters used for the removal of dyes from wastewater. Macromol. Symp. 2003, 203, 165-172. [CrossRef]

60. Crini, G. Studies on adsorption of dyes on beta-cyclodextrin polymer. Bioresour. Technol. 2003, 90, 193-198. [CrossRef]

61. Crini, G.; Morin, N.; Rouland, J.-C.; Janus, L.; Morcellet, M.; Bertini, S. Adsorption de béta-naphtol sur des gels de cyclodextrinecarboxyméthylcellulose réticulés. Eur. Polym. J. 2002, 38, 1095-1103. [CrossRef]

62. Crini, G. Recent developments in polysaccharide-based materials used as adsorbents in wastewater treatment. Prog. Polym. Sci. 2005, 30, 38-70. [CrossRef]

63. Janus, L.; Carbonnier, B.; Deratani, A.; Bacquet, M.; Crini, G.; Laureyns, J.; Morcellet, M. New HPLC stationary phases based on (methacryloyloxypropyl- $\beta$-cyclodextrin-co-N-vinylpyrrolidone) copolymers coated on silica. Preparation and characterisation. New J. Chem. 2003, 27, 307-312. [CrossRef]

64. Yu, J.C.; Jiang, Z.T.; Liu, H.Y.; Yu, L.; Zhang, L. b-cyclodextrin epichlorohydrin copolymer as a solid-phase extraction adsorbent for aromatic compounds in water samples. Anal. Chim. Acta 2003, 477, 93-101. [CrossRef]

65. Kitaoka, M.; Hayashi, K. Adsorption of bisphenol A by cross-linked $\beta$-cyclodextrin polymer. J. Incl. Phenom. Macrocycl. Chem. 2002, 44, 429-431. [CrossRef]

66. Mohseni, A.; Fan, L.; Roddick, F.; Li, H.; Gao, Y.; Liu, Z. Cationic starch: An effective flocculant for separating algal biomass from wastewater RO concentrate treated by microalgae. J. Appl. Phycol. 2021, 33, 917-928. [CrossRef]

67. Wang, J.-P.; Yuan, S.-J.; Wang, Y.; Yu, H.-Q. Synthesis, characterization and application of a novel starch-based flocculant with high flocculation and dewatering properties. Water Res. 2013, 47, 2643-2648. [CrossRef]

68. Anthony, R.; Sims, R. Cationic starch for microalgae and total phosphorus removal from wastewater. J. Appl. Polym. Sci. 2013, 130, 2572-2578. [CrossRef]

69. Moon, R.J.; Martini, A.; Nairn, J.; Simonsen, J.; Youngblood, J. Cellulose nanomaterials review: Structure, properties and nanocomposites. Chem. Soc. Rev. 2011, 40, 3941-3994. [CrossRef] [PubMed]

70. Ray, P.Z.; Shipley, H.J. Inorganic nano-adsorbents for the removal of heavy metals and arsenic: A review. RSC Adv. 2015, 5, 29885-29907. [CrossRef]

71. Trache, D.; Hussin, M.H.; Haafiz, M.M.; Thakur, V.K. Recent progress in cellulose nanocrystals: Sources and production. Nanoscale 2017, 9, 1763-1786. [CrossRef]

72. Mohammed, N.; Grishkewich, N.; Waeijen, H.A.; Berry, R.M.; Tam, K.C. Continuous flow adsorption of methylene blue by cellulose nanocrystal-alginate hydrogel beads in fixed bed columns. Carbohydr. Polym. 2016, 136, 1194-1202. [CrossRef]

73. Shatkin, J.; Wegner, T.; Neih, W. Incorporating life-cycle thinking into risk assessment for nanoscale materials: Case study of nanocellulose. In Production and Applications of Cellulose Nanomaterials; Rudie, A.W., Moon, R.J., Bilodeau, M.A., Postek, M.T., Eds.; TAPPI Press: Peachtree Corners, GA, USA, 2013; pp. 89-112.

74. Carpenter, A.W.; de Lannoy, C.-F.; Wiesner, M.R. Cellulose nanomaterials in water treatment technologies. Environ. Sci. Technol. 2015, 49, 5277-5287. [CrossRef]

75. Yin, J.; Deng, B. Polymer-matrix nanocomposite membranes for water treatment. J. Membr. Sci. 2015, 479, 256-275. [CrossRef]

76. Xie, X.L.; Mai, Y.W.; Zhou, X.P. Dispersion and alignment of carbon nanotubes in polymer matrix: A review. Mater. Sci. Eng. $R$ Rep. 2005, 49, 89-112. [CrossRef]

77. Varma, R.S. Greener and sustainable trends in synthesis of organics and nanomaterials. ACS Sustain. Chem. Eng. 2016, 4, 5866-5878. [CrossRef]

78. O'Connell, D.W.; Birkinshaw, C.; O'Dwyer, T.F. Heavy metal adsorbents prepared from the modification of cellulose: A review. Bioresour. Technol. 2008, 99, 6709-6724. [CrossRef]

79. Rezaee, A.; Pourtagi, G.; Hossini, H.; Loloi, M. Microbial cellulose as a support for photocatalytic oxidation of toluene using TiO 2 nanoparticles. J. Appl. Polym. Sci. 2016, 133. [CrossRef]

80. Jiang, F.; Hsieh, Y.-L. Amphiphilic superabsorbent cellulose nanofibril aerogels. J. Mater. Chem. A 2014, 2, 6337-6342. [CrossRef]

81. Wang, Y.; Zhang, X.; He, X.; Zhang, W.; Zhang, X.; Lu, C. In situ synthesis of $\mathrm{MnO}_{2}$ coated cellulose nanofibers hybrid for effective removal of methylene blue. Carbohydr. Polym. 2014, 110, 302-308. [CrossRef] [PubMed]

82. Riva, L.; Pastori, N.; Panozzo, A.; Antonelli, M.; Punta, C. Nanostructured Cellulose-Based Sorbent Materials for Water Decontamination from Organic Dyes. Nanomaterials 2020, 10, 1570. [CrossRef] [PubMed]

83. Yan, L.; Liu, B.; Li, W.; Zhao, T.; Wang, Y.; Zhao, Q. Multiscale cellulose based self-assembly of hierarchical structure for photocatalytic degradation of organic pollutant. Cellulose 2020, 27, 5241-5253. [CrossRef]

84. Mo, L.; Pang, H.; Tan, Y.; Zhang, S.; Li, J. 3D multi-wall perforated nanocellulose-based polyethylenimine aerogels for ultrahigh efficient and reversible removal of $\mathrm{Cu}$ (II) ions from water. Chem. Eng. J. 2019, 378, 122157. [CrossRef]

85. Johari, K.; Saman, N.; Song, S.T.; Chin, C.S.; Kong, H.; Mat, H. Adsorption enhancement of elemental mercury by various surface modified coconut husk as eco-friendly low-cost adsorbents. Int. Biodeterior. Biodegrad. 2016, 109, 45-52. [CrossRef]

86. Korhonen, J.T.; Kettunen, M.; Ras, R.H.; Ikkala, O. Hydrophobic nanocellulose aerogels as floating, sustainable, reusable, and recyclable oil absorbents. ACS Appl. Mater. Interfaces 2011, 3, 1813-1816. [CrossRef] 
87. Kang, H.; Liu, R.; Huang, Y. Graft modification of cellulose: Methods, properties and applications. Polymer 2015, 70, A1-A16. [CrossRef]

88. Salgueiro, A.M.; Daniel-da-Silva, A.L.; Girão, A.V.; Pinheiro, P.C.; Trindade, T. Unusual dye adsorption behavior of k-carrageenan coated superparamagnetic nanoparticles. Chem. Eng. J. 2013, 229, 276-284. [CrossRef]

89. Lapwanit, S.; Sooksimuang, T.; Trakulsujaritchok, T. Adsorptive removal of cationic methylene blue dye by kappacarrageenan/poly (glycidyl methacrylate) hydrogel beads: Preparation and characterization. J. Environ. Chem. Eng. 2018, 6, 6221-6230. [CrossRef]

90. Mittal, H.; Al Alili, A.; Alhassan, S.M. High efficiency removal of methylene blue dye using k-carrageenan-poly (acrylamide-comethacrylic acid)/AQSOA-Z05 zeolite hydrogel composites. Cellulose 2020, 27, 8269-8285. [CrossRef]

91. Prasannan, A.; Udomsin, J.; Tsai, H.-C.; Wang, C.-F.; Lai, J.-Y. Robust underwater superoleophobic membranes with bio-inspired carrageenan/laponite multilayers for the effective removal of emulsions, metal ions, and organic dyes from wastewater. Chem. Eng. J. 2020, 391, 123585. [CrossRef]

92. Lv, D.; Li, Y.; Wang, L. Carbon aerogels derived from sodium lignin sulfonate embedded in carrageenan skeleton for methyleneblue removal. Int. J. Biol. Macromol. 2020, 148, 979-987. [CrossRef]

93. Abdellatif, M.M.; Soliman, S.M.A.; El-Sayed, N.H.; Abdellatif, H.H. Iota-carrageenan based magnetic aerogels as an efficient adsorbent for heavy metals from aqueous solutions. J. Porous Mater. 2020, 27, 277-284. [CrossRef]

94. Cañizares, R.; Rivas, L.; Montes, C.; Dominguez, A.; Travieso, L.; Benitez, F. Aerated swine-wastewater treatment with Kcarrageenan-immobilized Spirulina maxima. Bioresour. Technol. 1994, 47, 89-91. [CrossRef]

95. Ahmed, M.A.; Abdelbar, N.M.; Mohamed, A.A. Molecular imprinted chitosan- $\mathrm{TiO}_{2}$ nanocomposite for the selective removal of Rose Bengal from wastewater. Int. J. Biol. Macromol. 2018, 107, 1046-1053. [CrossRef]

96. Xu, C.; Nasrollahzadeh, M.; Selva, M.; Issaabadi, Z.; Luque, R. Waste-to-wealth: Biowaste valorization into valuable bio (nano) materials. Chem. Soc. Rev. 2019, 48, 4791-4822. [CrossRef]

97. An, B.; Lee, H.; Lee, S.; Lee, S.-H.; Choi, J.-W. Determining the selectivity of divalent metal cations for the carboxyl group of alginate hydrogel beads during competitive sorption. J. Hazard. Mater. 2015, 298, 11-18. [CrossRef]

98. Idris, A.; Ismail, N.S.M.; Hassan, N.; Misran, E.; Ngomsik, A.-F. Synthesis of magnetic alginate beads based on maghemite nanoparticles for $\mathrm{Pb}$ (II) removal in aqueous solution. J. Ind. Eng. Chem. 2012, 18, 1582-1589. [CrossRef]

99. Kuang, Y.; Du, J.; Zhou, R.; Chen, Z.; Megharaj, M.; Naidu, R. Calcium alginate encapsulated Ni/Fe nanoparticles beads for simultaneous removal of $\mathrm{Cu}$ (II) and monochlorobenzene. J. Colloid Interface Sci. 2015, 447, 85-91. [CrossRef] [PubMed]

100. Li, X.; Qi, Y.; Li, Y.; Zhang, Y.; He, X.; Wang, Y. Novel magnetic beads based on sodium alginate gel crosslinked by zirconium (IV) and their effective removal for $\mathrm{Pb}^{2+}$ in aqueous solutions by using a batch and continuous systems. Bioresour. Technol. 2013, 142, 611-619. [CrossRef] [PubMed]

101. Li, J.; Mo, L.; Lu, C.-H.; Fu, T.; Yang, H.-H.; Tan, W. Functional nucleic acid-based hydrogels for bioanalytical and biomedical applications. Chem. Soc. Rev. 2016, 45, 1410-1431. [CrossRef] [PubMed]

102. Wang, S.; Vincent, T.; Roux, J.-C.; Faur, C.; Guibal, E. Pd (II) and Pt (IV) sorption using alginate and algal-based beads. Chem. Eng. J. 2017, 313, 567-579. [CrossRef]

103. Gupta, V.K.; Yola, M.L.; Eren, T.; Kartal, F.; Çağlayan, M.O.; Atar, N. Catalytic activity of Fe@Ag nanoparticle involved calcium alginate beads for the reduction of nitrophenols. J. Mol. Liq. 2014, 190, 133-138. [CrossRef]

104. Wu, N.; Wei, H.; Zhang, L. Efficient removal of heavy metal ions with biopolymer template synthesized mesoporous titania beads of hundreds of micrometers size. Environ. Sci. Technol. 2012, 46, 419-425. [CrossRef]

105. Zheng, W.; An, Q.; Lei, Z.; Xiao, Z.; Zhai, S.; Liu, Q. Efficient batch and column removal of Cr (VI) by carbon beads with developed nano-network. RSC Adv. 2016, 6, 104897-104910. [CrossRef]

106. Cheng, Y.; Luo, X.; Payne, G.F.; Rubloff, G.W. Biofabrication: Programmable assembly of polysaccharide hydrogels in microfluidics as biocompatible scaffolds. J. Mater. Chem. 2012, 22, 7659-7666. [CrossRef]

107. Topuz, F.; Henke, A.; Richtering, W.; Groll, J. Magnesium ions and alginate do form hydrogels: A rheological study. Soft Matter 2012, 8, 4877-4881. [CrossRef]

108. Yang, C.H.; Wang, M.X.; Haider, H.; Yang, J.H.; Sun, J.-Y.; Chen, Y.M.; Zhou, J.; Suo, Z. Strengthening alginate/polyacrylamide hydrogels using various multivalent cations. ACS Appl. Mater. Interfaces 2013, 5, 10418-10422. [CrossRef]

109. Dodero, A.; Vicini, S.; Lova, P.; Alloisio, M.; Castellano, M. Nanocomposite alginate-based electrospun membranes as novel adsorbent systems. Int. J. Biol. Macromol. 2020, 165, 1939-1948. [CrossRef] [PubMed]

110. Ahmad, R.; Mirza, A. Sequestration of heavy metal ions by Methionine modified bentonite/Alginate (Meth-bent/Alg): A bionanocomposite. Groundw. Sustain. Dev. 2015, 1, 50-58. [CrossRef]

111. Ahmadi, M.; Rahmani, H.; Takdastan, A.; Jaafarzadeh, N.; Mostoufi, A. A novel catalytic process for degradation of bisphenol A from aqueous solutions: A synergistic effect of nano- $\mathrm{Fe}_{3} \mathrm{O}_{4} @ \mathrm{Alg}-\mathrm{Fe}$ on $\mathrm{O}_{3} / \mathrm{H}_{2} \mathrm{O}_{2}$. Process Saf. Environ. Protect. 2016, 104, 413-421. [CrossRef]

112. Asadi, S.; Eris, S.; Azizian, S. Alginate-Based Hydrogel Beads as a Biocompatible and Efficient Adsorbent for Dye Removal from Aqueous Solutions. ACS Omega 2018, 3, 15140-15148. [CrossRef]

113. Parlayici, Ş. Alginate-coated perlite beads for the efficient removal of methylene blue, malachite green, and methyl violet from aqueous solutions: Kinetic, thermodynamic, and equilibrium studies. J. Anal. Sci. Technol. 2019, 10, 4. [CrossRef] 
114. Mahmoodi, N.M.; Hayati, B.; Arami, M.; Bahrami, H. Preparation, characterization and dye adsorption properties of biocompatible composite (alginate/titania nanoparticle). Desalination 2011, 275, 93-101. [CrossRef]

115. Rezaei, H.; Haghshenasfard, M.; Moheb, A. Optimization of dye adsorption using $\mathrm{Fe}_{3} \mathrm{O}_{4}$ nanoparticles encapsulated with alginate beads by Taguchi method. Adsorpt. Sci. Technol. 2017, 35, 55-71. [CrossRef]

116. Radoor, S.; Karayil, J.; Parameswaranpillai, J.; Siengchin, S. Removal of anionic dye Congo red from aqueous environment using polyvinyl alcohol/sodium alginate/ZSM-5 zeolite membrane. Sci. Rep. 2020, 10, 15452. [CrossRef]

117. Wang, J.; Zhuang, S. Removal of various pollutants from water and wastewater by modified chitosan adsorbents. Crit. Rev. Environ. Sci. Technol. 2017, 47, 2331-2386. [CrossRef]

118. Kanmani, P.; Aravind, J.; Kamaraj, M.; Sureshbabu, P.; Karthikeyan, S. Environmental applications of chitosan and cellulosic biopolymers: A comprehensive outlook. Bioresour. Technol. 2017, 242, 295-303. [CrossRef]

119. Gibbs, G.; Tobin, J.M.; Guibal, E. Sorption of Acid Green 25 on chitosan: Influence of experimental parameters on uptake kinetics and sorption isotherms. J. Appl. Polym. Sci. 2003, 90, 1073-1080. [CrossRef]

120. Saha, T.K.; Ichikawa, H.; Fukumori, Y. Gadolinium diethylenetriaminopentaacetic acid-loaded chitosan microspheres for gadolinium neutron-capture therapy. Carbohydr. Res. 2006, 341, 2835-2841. [CrossRef]

121. Rinaudo, M. Chitin and chitosan: Properties and applications. Prog. Polym. Sci. 2006, 31, 603-632. [CrossRef]

122. Gopi, S.; Balakrishnan, P.; Divya, C.; Valic, S.; Bajsic, E.G.; Pius, A.; Thomas, S. Facile synthesis of chitin nanocrystals decorated on $3 \mathrm{D}$ cellulose aerogels as a new multi-functional material for waste water treatment with enhanced anti-bacterial and anti-oxidant properties. New J. Chem. 2017, 41, 12746-12755. [CrossRef]

123. Marrakchi, F.; Khanday, W.; Asif, M.; Hameed, B. Cross-linked chitosan/sepiolite composite for the adsorption of methylene blue and reactive orange 16. Int. J. Biol. Macromol. 2016, 93, 1231-1239. [CrossRef] [PubMed]

124. Kadam, A.A.; Lee, D.S. Glutaraldehyde cross-linked magnetic chitosan nanocomposites: Reduction precipitation synthesis, characterization, and application for removal of hazardous textile dyes. Bioresour. Technol. 2015, 193, 563-567. [CrossRef]

125. Chang, Y.C.; Chen, D.H. Adsorption kinetics and thermodynamics of acid dyes on a carboxymethylated chitosan-conjugated magnetic nano-adsorbent. Macromol. Biosci. 2005, 5, 254-261. [CrossRef]

126. Shoueir, K.; Kandil, S.; El-hosainy, H.; El-Kemary, M. Tailoring the surface reactivity of plasmonic $\mathrm{Au} @ \mathrm{TiO}_{2}$ photocatalyst bio-based chitosan fiber towards cleaner of harmful water pollutants under visible-light irradiation. J. Clean. Prod. 2019, 230, 383-393. [CrossRef]

127. Karimi, M.H.; Mahdavinia, G.R.; Massoumi, B.; Baghban, A.; Saraei, M. Ionically crosslinked magnetic chitosan/ k-carrageenan bioadsorbents for removal of anionic eriochrome black-T. Int. J. Biol. Macromol. 2018, 113, 361-375. [CrossRef]

128. Qiu, Y.; Ma, Z.; Hu, P. Environmentally benign magnetic chitosan $/ \mathrm{Fe}_{3} \mathrm{O}_{4}$ composites as reductant and stabilizer for anchoring Au NPs and their catalytic reduction of 4-nitrophenol. J. Mater. Chem. A 2014, 2, 13471-13478. [CrossRef]

129. Anaya-Esparza, L.M.; Ruvalcaba-Gómez, J.M.; Maytorena-Verdugo, C.I.; González-Silva, N.; Romero-Toledo, R.; AguileraAguirre, S.; Pérez-Larios, A.; Montalvo-González, E. Chitosan- $\mathrm{TiO}_{2}$ : A versatile hybrid composite. Materials 2020, 13, 811. [CrossRef]

130. Li, W.; Xiao, L.; Qin, C. The characterization and thermal investigation of chitosan- $\mathrm{Fe}_{3} \mathrm{O}_{4}$ nanoparticles synthesized via a novel one-step modifying process. J. Macromol. Sci. Part A 2010, 48, 57-64. [CrossRef]

131. Rajeswari, A.; Amalraj, A.; Pius, A. Adsorption studies for the removal of nitrate using chitosan/PEG and chitosan/PVA polymer composites. J. Water Process Eng. 2016, 9, 123-134. [CrossRef]

132. Borsagli, F.G.M.; Mansur, A.A.; Chagas, P.; Oliveira, L.C.; Mansur, H.S. O-carboxymethyl functionalization of chitosan: Complexation and adsorption of Cd (II) and Cr (VI) as heavy metal pollutant ions. React. Funct. Polym. 2015, 97, 37-47. [CrossRef]

133. Rahimi, S.; Moattari, R.M.; Rajabi, L.; Derakhshan, A.A. Optimization of lead removal from aqueous solution using goethite/chitosan nanocomposite by response surface methodology. Colloids Surf. A Physicochem. Eng. Asp. 2015, 484, 216-225. [CrossRef]

134. Pincus, L.N.; Melnikov, F.; Yamani, J.S.; Zimmerman, J.B. Multifunctional photoactive and selective adsorbent for arsenite and arsenate: Evaluation of nano titanium dioxide-enabled chitosan cross-linked with copper. J. Hazard. Mater. 2018, 358, 145-154. [CrossRef] [PubMed]

135. Abdi, S.; Nasiri, M.; Mesbahi, A.; Khani, M. Investigation of uranium (VI) adsorption by polypyrrole. J. Hazard. Mater. 2017, 332, 132-139. [CrossRef] [PubMed]

136. Zhang, Y.-J.; Xue, J.-Q.; Li, F.; Dai, J.-Z. Preparation of polypyrrole/chitosan/carbon nanotube composite nano-electrode and application to capacitive deionization process for removing $\mathrm{Cu}^{2+}$. Chem. Eng. Process. Process Intensif. 2019, 139, 121-129. [CrossRef]

137. Wang, J.-P.; Chen, Y.-Z.; Yuan, S.-J.; Sheng, G.-P.; Yu, H.-Q. Synthesis and characterization of a novel cationic chitosan-based flocculant with a high water-solubility for pulp mill wastewater treatment. Water Res. 2009, 43, 5267-5275. [CrossRef] [PubMed]

138. Chen, L.; Cao, W.; Quinlan, P.J.; Berry, R.M.; Tam, K.C. Sustainable catalysts from gold-loaded polyamidoamine dendrimercellulose nanocrystals. ACS Sustain. Chem. Eng. 2015, 3, 978-985. [CrossRef]

139. Muraleedaran, K.; Mujeeb, V.A. Applications of chitosan powder with in situ synthesized nano ZnO particles as an antimicrobial agent. Int. J. Biol. Macromol. 2015, 77, 266-272.

140. Hamdi, A.; Boufi, S.; Bouattour, S. Phthalocyanine/chitosan- $\mathrm{TiO}_{2}$ photocatalysts: Characterization and photocatalytic activity. Appl. Surf. Sci. 2015, 339, 128-136. [CrossRef] 
141. Neghi, N.; Kumar, M.; Burkhalov, D. Synthesis and application of stable, reusable $\mathrm{TiO}_{2}$ polymeric composites for photocatalytic removal of metronidazole: Removal kinetics and density functional analysis. Chem. Eng. J. 2019, 1, 963-975. [CrossRef]

142. Antony, R.; Marimuthu, R.; Murugavel, R. Bimetallic Nanoparticles Anchored on Core-Shell Support as an Easily Recoverable and Reusable Catalytic System for Efficient Nitroarene Reduction. ACS Omega 2019, 4, 9241-9250. [CrossRef] [PubMed]

143. Arvand, M.; Latify, L.; Tajmehri, H.; Yagubov, A.I.; Nuriyev, A.N.; Pourhabib, A.; Mousavi, S.J.; Abolhassani, M.R. Comparative study for the removal of oxadiazon from aqueous solutions by adsorption on chitosan and activated carbon. Anal. Lett. 2009, 42, 856-869. [CrossRef]

144. Mi, F.-L.; Shyu, S.-S.; Chen, C.-T.; Lai, J.-Y. Adsorption of indomethacin onto chemically modified chitosan beads. Polymer 2002, 43, 757-765. [CrossRef]

145. Wysokińska, Z. A Market for Starch, Hemicellulose, Cellulose, Alginate, its Salts and Esters, and Natural Polymers, including Chitin and Chitosan: Analysis Results. Fibres Text. East. Eur. 2010, 18, 7-13. 